Chirurgia (2021) 116: 339-346

No. 3, May-June

Copyright@ Celsius

http://dx.doi.org/10.21614/chirurgia.116.3.339

\title{
COVID-19 in Liver Transplant Recipients - Preliminary Experience of a Bulgarian Center
}

\author{
Ivelin Takorov', Tsonka Lukanova', Maria Abrasheva², Stefan Arnaudov', Stefan Simeonovski', \\ Dimitria Vylcheva', Dimitar Dimitrov', Tsvetan Stanimirov' ${ }^{1}$
}

${ }^{1}$ First Clinic of Abdominal Surgery, Military Medical Academy, Sofia, Bulgaria

2Department of Anesthesiology and Intensive Care, Military Medical Academy, Sofia, Bulgaria

*Corresponding author: Tsonka Lukanova, MD, PhD First Clinic of Abdominal Surgery Military Medical Academy, 3. Georgi Sofiiski, str., Sofia, 1606 E-mail: priluki@abv.bg
Received: 06.02.2021 Accepted: 17.04 .2021

\section{Rezumat}

COVID-19 la pacienții cu transplant hepatic - experiența preliminară a unui centru bulgar

Introducere: Există controverse cu privire la estimarea riscului şi severității infecției cu noul coroavirus (COVID-19) la pacienții cu transplant hepatic, precum şi cu privire la evaluarea impactului terapiei imunosupresoare asupra evoluției clinice şi incidenței insuficienței hepatice.

Material şi metode: Acest studiu este de tip prospectiv şi include pacienții cunoscuți cu transplant hepatic în antecedente, diagnosticați cu infectii respiratorii acute severe cu virsul SARS-CoV-2, internați pentru tratament în departamentul Clinicii I de Chirurgie Abdominală al Academiei Medicale Militare din Sofia, în perioada 25.11.2020 - 04.01.2021. Diagnosticul infecției cu SARSCoV-2 a fost confirmat printr-un test pozitiv al reacției de polimerizare în lanț cu revers transcriptaza (RT-PCR) din exudatul nazo-faringian. Severitatea COVID-19 a fost estimată ca fiind uşoară (saturație în oxigen $(\mathrm{SpO} 2) \geq 94 \%$ în aerul ambiental şi fără rezultate imagistice sugestive pentru pneumonie), moderată (SpO2 <94\%, imagini radiologice sugestive pentru pneumonie) şi severă (necesitatea suplimentării cu oxigen cu debit mare).

Rezultate: Trei pacienti care au primit un transplant hepatic şi au fost diagnosticați infecție COVID-19 au fost internați şi tratați în departamentul nostru în perioada 25.11.2020 - 04.01.2021. Pacienții sunt de sex masculin, cu vârsta medie de 51,33 ani (47 59), iar transplanturile hepatice au fost efectuate cu 13,5 şi 1,5 ani anterior. La fiecare dintre cei trei pacienți s-a înregistrat o formă clinică diferită a bolii - uşoară $(n=1)$, moderată $(n=1)$ şi severă $(n=1)$. Doar pacientul cu boală severă avea comorbidități hipertensiune, diabet şi obezitate. Pacienții cu boală uşoară şi 
moderată au primit dublu tratament imunosupresor cu tacrolimus şi micofenolat de mofetil, în timp ce pacientul cu boală severă a primit doar tacrolimus. $\mathrm{O}$ reducere a dozei de tacrolimus a fost întreprinsă după evaluarea nivelului seric, fără modificarea dozei de micofenolat mofetil în cazul pacienților aflați în tratament dual. Pacientul cu boală severă a decedat din cauza insuficienței respiratorii, ducând la o rată de fatalitate de $33,3 \%$.

Concluzie: Diagnosticul precoce şi spitalizarea, atunci când este posibil, sunt esențiale pentru inițierea promptă a tratamentului, prevenirea complicațiilor şi a dezvoltării formelor severe de COVID-19 la pacienții cu transplant hepatic, în special la pacienții cu comorbidități precum hipertensiunea, diabetul şi obezitatea. Pe parcursul tratamentului, se poate încerca o reducere a dozelor terapiei imunosupresoare, dar nu întreruperea tratamentului, în special a inhibitorului calcineurinei în mono- sau dublă terapie.

Cuvinte cheie: COVID-19, transplant hepatic

\begin{abstract}
Introduction: There are still debatable facts about estimating the risk and severity of coronavirus disease (COVID-19) in liver transplant recipients, as well as assessing the impact of the immunosuppressive therapy on the clinical course and incidence of liver failure.

Material and methods: We present a prospective study of liver transplant recipients with severe acute respiratory syndrome coronavirus (SARS-CoV-2) infection admitted for treatment to the department of First Clinic of Abdominal Surgery, Military Medical Academy, Sofia during 25.11.2020 - 04.01.2021. The diagnosis is confirmed by a positive reverse transcription polymerase chain reaction (RT-PCR) test for SARS-CoV-2 infection from a naso-pharyngeal swab. COVID-19 severity is estimated as mild (oxygen saturation $(\mathrm{SpO} 2) \geq 94 \%$ on room air and no imaging findings of pneumonia), moderate (SpO2<94\%, imaging suggestive of pneumonia), and severe (need for high flow oxygen supplementation).

Results: Three liver transplant recipients with COVID-19 were admitted and treated in our department during 25.11.2020 - 04.01.2021. All of them were male, mean age of 51.33 years (47 59) and their liver transplantations were performed 13,5 , and 1.5 years before. In each of the three patients a different clinical form of the disease was registered - mild $(n=1)$, moderate $(n=1)$, and severe $(n=1)$. Only the patient with severe disease had comorbidities - hypertension, diabetes, and obesity. The patients with mild and moderate disease received dual immunosuppressive therapy with tacrolimus and mycophenolate mofetil while the one with severe disease - tacrolimus only. A dose reduction of tacrolimus was undertaken following serum level evaluation without changing the dose of the mycophenolate mofetil for those on dual therapy. The patient with severe disease died from respiratory failure leading to a case fatality rate of $33.3 \%$.

Conclusion: Early diagnosis and hospitalization where possible are essential for the prompt initiation of treatment, prevention of complications and development of severe forms of COVID-19 in liver transplant recipients, especially in patients with comorbidities such as hypertension, diabetes, and obesity. During the course of treatment there may be a dose reduction of the immunosuppressive therapy but not discontinuation, especially of the calcineurin inhibitor in mono- or dual-therapy regimens.
\end{abstract}

Key words: COVID-19, liver transplantation 


\section{Introduction}

Nearly a year after the World Health Organization (WHO) declared a world severe acute respiratory syndrome coronavirus 2 (SARS-CoV-2) pandemic on 11.03.2020 (1), there are still disputable facts concerning the evolution and treatment of the coronavirus disease (COVID-19) in liver transplant recipients. Of particular interest and more specific are those assessing risk stratification and disease severity, as well as the effect of chronic immune suppression therapy and hepatic impairment. The following study represents our preliminary experience in the treatment of COVID-19 in liver transplant patients.

\section{Methods}

We present prospective observational data of patients who had undergone liver transplantation (LT) and admitted for treatment with clinical signs of SARS-CoV-2 infection to the department of First Clinic of Abdominal Surgery (FCAS), Military Medical Academy, Sofia, Bulgaria during 25.11.2020 - 04.01.2021. The diagnostic and therapeutic approach were conducted by a multidisciplinary team that consisted of general surgeons, anesthesiologist, infectious disease physician, gastroenterologist, respiratory physician, radiologist, virologist, laboratory physician, and physiotherapist. As a definition of SARS-CoV-2 infection, along with WHO recommendations, we accepted a positive laboratory confirmation of SARS-CoV-2 infection irrespective of clinical signs and symptoms (2). The diagnosis in our institution was confirmed by a positive reverse transcription polymerase chain reaction (RT-PCR) test from a naso-pharyngeal swab. The common characteristics of the imaging modalities are bilateral ground glass opacifications and/or areas of consolidation on a chest X-ray or chest computed tomography (CT) scan (3). The Covid-19 disease severity is considered mild (oxygen saturation $(\mathrm{SpO} 2) \geq 94 \%$ on room air and no imaging findings of pneumonia); moderate $(\mathrm{SpO} 2<94 \%$ on room air and imaging suggestive of pneumonia), and severe (need for high flow oxygen supplementation) (4). The most severe form of the disease was registered during the treatment. The degree of acute liver injury is defined by the levels of alanine aminotransferase (ALT) during the peak of COVID-19 disease and is graded as follows: no hepatic impairment (ALT $<2 \mathrm{x}$ upper limit of normal (ULN) reference range); moderate liver injury (ALT $=2-5 \mathrm{x}$ ULN), and severe liver injury (ALT > 5x ULN) (5). The treatment was conducted in accordance with the approved Covid-19 treatment protocols in our institution at the time of admission after obtaining an informed consent from the patient.

\section{Results}

Three liver transplant recipients with COVID-19 were admitted and treated in our department (FCAS) for the period 25.11.2020 04.01.2021.All of them are male at a mean age of 51.33 years $(47-59)$ and their liver transplantations were performed 13,5 , and 1.5 years ago. The demographic characteristics and clinical presentation are presented in Table 1. The most common symptoms were dry cough, fever, and fatigue. Only one of the patients had reported the presence of diarrhea. In each of the three patients a different clinical form of the disease was registered - mild $(n=1)$, moderate $(n=1)$, and severe $(n=1)$. The patient with the mild form of the disease was hospitalized on the $4^{\text {th }}$ day of symptom appearance and the one with the severe form - on the 6th day. The third patient who developed a moderate Covid-19 disease was initially admitted with cholangitis and was later found to be positive for a SARS$\mathrm{CoV}-2$ infection due to pyrexia after bile duct re-stenting. Only the patient with severe disease had hypertension, diabetes mellitus, and obesity as co-morbidities.

The main laboratory findings are summarized in Table 2. Standard blood count deviations and inflammatory marker changes were registered in all patients. Liver enzyme elevation at different rate was registered, 
Table 1. Demographic characteristics and clinical presentation in liver transplant recipients with Covid-19 disease

\begin{tabular}{|c|c|c|c|}
\hline Variables & Patient 1 & Patient 2 & Patient 3 \\
\hline Age (years) & 59 & 47 & 58 \\
\hline Time after LT (years) & 1.5 & 13 & 5 \\
\hline Reason for LT & alcoholic liver cirrhosis & multiple hemangioendothelioma & hepatitis C virus-cirrhosis \\
\hline $\begin{array}{l}\text { Type of immunosuppression } \\
\text { before admission }\end{array}$ & $\begin{array}{l}\text { tacrolimus + mycophenolate } \\
\text { mofetil }\end{array}$ & $\begin{array}{l}\text { tacrolimus }+ \\
\text { mycophenolate mofetil }\end{array}$ & tacrolimus \\
\hline \multicolumn{3}{|l|}{ Time between admission and } & 6 \\
\hline $\mathrm{BMI}, \mathrm{kg} / \mathrm{m}^{2}$ & 24 & 20 & 32 \\
\hline \multicolumn{4}{|l|}{ Co-morbidities } \\
\hline Arterial hypertension & no & no & yes \\
\hline Diabetes mellitus & no & no & yes \\
\hline Obesity & no & no & yes \\
\hline Clinical manifestation & $\begin{array}{l}\text { fever up to } 37.7 \mathrm{C}^{\circ} \text {, } \\
\text { dry cough }\end{array}$ & $\begin{array}{l}\text { fever up to } 39 \mathrm{C}^{\circ} \text {, } \\
\text { tiredness }\end{array}$ & $\begin{array}{l}\text { fever up to } 38.6 \mathrm{C} \mathrm{C}^{\circ} \text {, } \\
\text { dry cough, diarrhea }\end{array}$ \\
\hline COVID-19 severity & mild & moderate & severe \\
\hline Hospital stay (days) & 16 & 19 & 9 \\
\hline ICU admission (days) & - & - & 9 \\
\hline Outcome & discharged & discharged & deceased \\
\hline
\end{tabular}

Note: LT - liver transplantation; BMI - body mass index; ICU - intensive care unit

Table 2. Laboratory studies in liver transplant recipients with COVID-19

\begin{tabular}{|c|c|c|c|}
\hline Variables, mean (IQR) & $\begin{array}{l}\text { Patient } 1 \\
\text { (mild COVID-19) }\end{array}$ & $\begin{array}{l}\text { Patient } 2 \\
\text { (moderate COVID-19) }\end{array}$ & $\begin{array}{l}\text { Patient } 3 \\
\text { (severe COVID-19) }\end{array}$ \\
\hline \multicolumn{4}{|l|}{ Inflammatory markers } \\
\hline $\mathrm{LDH}, \mathrm{U} / \mathrm{I}$ & $432(338-487)$ & $384(306-429)$ & $1268(985-1685)$ \\
\hline Ferritin, ng/ml & $515.34(434-556)$ & $1465(1342-1527)$ & $964(563-1314)$ \\
\hline $\mathrm{CRP}, \mathrm{mg} / \mathrm{l}$ & $26.34(11.6-33.7)$ & $53.4(0.1-96.6)$ & $126.4(39-180.2)$ \\
\hline D-Dimers, $\mu \mathrm{g} / \mathrm{ml}$ & $0.36(0.29-0.4)$ & $1.09(0.28-1.49)$ & $1.72(1.02-2.24)$ \\
\hline Procalcitonin, ng/ml & $0.74(0.57-1.03)$ & $0.95(0.74-1.14)$ & $2.78(2.43-2.96)$ \\
\hline IL-6, pg/ml & $16.03(2.42-1.74)$ & $4.02(2.96-4.55)$ & $74.34(27.02-98.05)$ \\
\hline \multicolumn{4}{|l|}{ Blood cell count } \\
\hline Leucocytes, $(\mathrm{X} 1000 / \mu \mathrm{L})$ & $4.63(3.5-6.89)$ & $3.09(1.88-4.08)$ & $2.51(1.84-3.36)$ \\
\hline Lymphocytes, (X1000/ $\mu \mathrm{L})$ & $0.96(0.68-1.1)$ & $1.35(0.9-1.57)$ & $0.26(0.1-0.64)$ \\
\hline Eosinophils, $(X 1000 / \mu \mathrm{L})$ & $0.03(0.0-0.05)$ & $0.01(0.0-0.03)$ & $0.0(0.0-0.0)$ \\
\hline \multicolumn{4}{|l|}{ Biochemistry } \\
\hline total bilirubin, $\mu \mathrm{mol} / \mathrm{l}$ & $9.37(7.7-10.2)$ & $95.93(30.6-28.6)$ & $21(16.3-24.9)$ \\
\hline ASAT, U/I & $19.7(18.0-21.4)$ & $170.06(84.8-305.4)$ & $215(41-302)$ \\
\hline ALAT, U/I & $49.57(31.0-74.4)$ & $185.86(101.9-332.3)$ & $165(23-309)$ \\
\hline Creatinine, $\mu \mathrm{mol} / \mathrm{l}$ & $99.34(96.0-101.0)$ & $75(66.0-80.0)$ & $194(155-222)$ \\
\hline INR & $1.05(1.0-1.09)$ & $1.06(1.01-1.09)$ & $1.56(1.04-1.34)$ \\
\hline Albumin, $(g / l)$ & $38.23(37.9-39.4)$ & $34.36(29.9-39.4)$ & $25.9(22.6-30.1)$ \\
\hline Tacrolimus serum level, $\mu \mathrm{g} / \mathrm{l}$ & $6.6(6.1-7.1)$ & $6.8(3.8-9.5)$ & $5.2(3.3-8.9)$ \\
\hline MELD score on admission & 8 & 15 & 12 \\
\hline
\end{tabular}

Note: LDH - lactate dehydrogenase; CRP - C-reactive protein, IL-6 - interleukin-6; ASAT - aspartate aminotransferase;

ALAT - alanine aminotransferase; INR - international normalized ratio; MELD - model for end-stage liver disease

ranged from $1.85-7.7-8.3$ times above ULN. The highest MELD score (15) on admission was that of the patient with moderate COVID-19, due to existing biliary infection and deteriorated bilirubin levels.

The patient with mild disease did not have any radiological evidence of lung changes. The patients with moderate and severe form of COVID-19 had the typical bilateral, predominantly sub-pleural widespread areas of ground glass opacifications showing tendency of progression and developing into areas of consolidation (Fig. 1).

Superimposed bacterial infection was iden- 

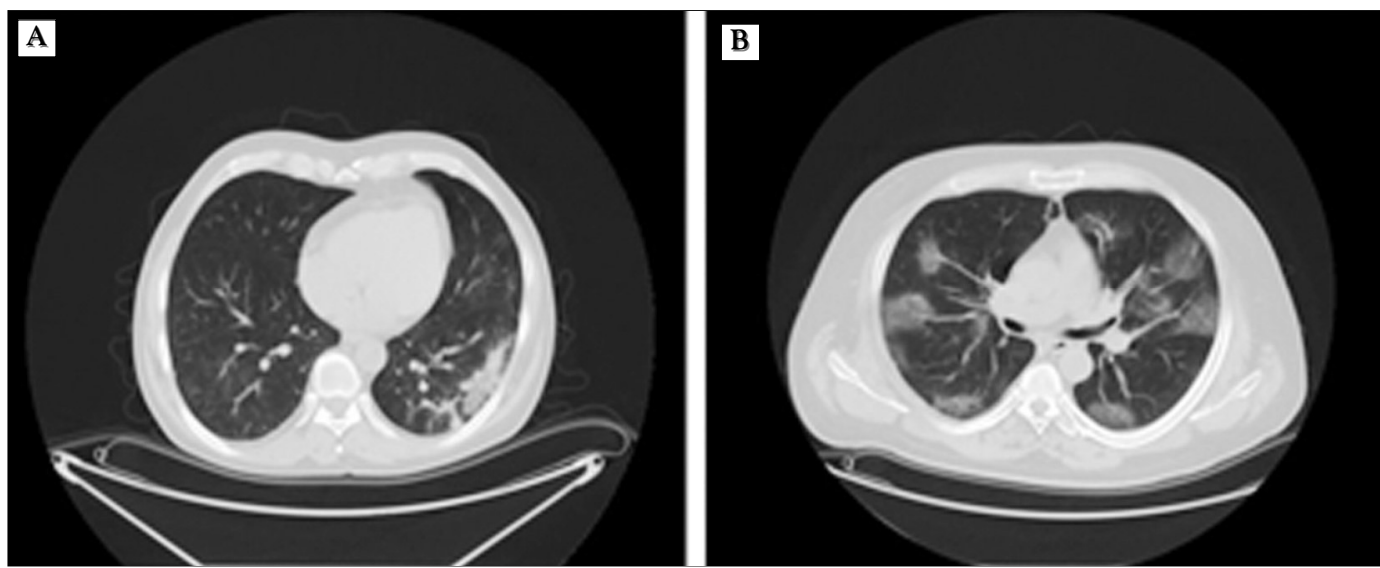

Figure 1. Computed tomography chest scan in patients with moderate (A) and severe (B) form of COVID-19 typical bilateral, predominantly sub-pleural widespread areas of ground glass opacifications (B) showing tendency of progression and developing into areas of consolidation (A).

tified in two patients. In one of them it was referred to as suspected due to the presence of cholangitis and the performed endoscopic retrograde cholangio-pancreatography with biliary re-stenting despite the lack of positive microbiology cultures on the background of a typical laboratory study constellation for bacterial infection. Enterococcus casseliflavus was isolated from trachea-bronchial aspirate from the second patient on the $5^{\text {th }}$ day after endotracheal intubation, which is a rare vancomycin-resistant enterococcus and was treated with linezolid.

The patients with mild and moderate disease were on a combined immunosuppressive therapy with tacrolimus and mycophenolate mofetil, while the one with the severe form was on tacrolimus only. None of them had been on steroid treatment prior to admission. Tacrolimus serum levels in all three patients were measured and decision of dose reduction without changing the dose of the mycophenolate mofetil for those on combined therapy was made. Steroid treatment (methylprednisolone and dexamethasone) was initiated for the patients with moderate and severe disease according to their inflammatory profile. After negative antibody essays the patient with severe disease received convalescent Covid-19 plasma. He was the only one who had a 5-day antiviral treatment course with remdesivir. All three patients received combination of two antibiotics (without azithromycin) together with an antifungal agent (fluconazole) considering its effect on the tacrolimus serum levels. The patient with moderate disease received oxygen therapy via facemask up to $91 / \mathrm{min}$, while the patient with the severe form of the disease was given highflow oxygen therapy before he was admitted to ICU and put on mechanical ventilation. Negative SARS-CoV-2RT-PCR tests were confirmed for the patients with mild and moderate disease on day 15 and 17 respectively of the hospital stay. The mortality rate was $33.33 \%$. We had one lethal case - the patient with the severe form of COVID-19 - as a consequence of respiratory failure on the 9-th day of intubation and ICU-treatment. The mean hospital stay was 17.7 days (16-19).

\section{Discussion}

We present our initial experience with three liver transplant recipients with SARS-CoV-2 infection during 25.11.2020 - 04.01.2021. The treatment was conducted in a surgical department at the peak of the morbidity rates from SARS-CoV-2 in Bulgaria so far, which prompted the disclosure and use of beds for infectious disease treatment in nonspecialized structures for the purpose. All three patients were men. Male gender prevails in other studies as well $(6,8)$. In a European prospective 
multicenter study which included 57 patients, $70 \%$ were men (7).

Contrary to other authors' reports (4), gastrointestinal (GI) symptoms were not common in our patients. Fever and cough are the most prevalent clinical signs according to a large-scale study from Spain - respectively in $74.8 \%$ and $70.3 \%$ of all cases (9). In an epidemiological study from Iran, the leading symptom was dyspnea, while gastro-intestinal symptoms were not reported (6). In a European prospective multicenter study, the most common clinical signs were fever (79\%), cough $(55 \%)$, dyspnea $(46 \%)$, fatigue or myalgia (56\%), and GI symptoms (33\%), while anosmia or dysgeusia were observed in only $7 \%$ of all cases (7).

The reason for admission of all our patients was SARS-CoV-2 infection regardless of their comorbidities or older age in contrast to other authors $(4,7,14)$. This is most likely due to the smaller number of liver transplant recipients in Bulgaria which allows a more thorough follow up in each medical aspect. There is an interesting report from Iran in which, despite the fact that all transplant patients were quarantined at the end of February 2020 when SARS-CoV-2 was encountered in Iran for the first time (second country in the world after China), there was a degree of misinterpretation of symptoms as "common cold" as well as not specified protocols for quarantine, which led to complications, delayed hospital admission, and delayed treatment (6). Clarifying the symptoms and paying attention even to the slightest changes in the patients' general health are of paramount importance for the early diagnosis, hospitalization where possible and initiation of treatment under strict clinical observation.

We observed standard deviations in the blood cell count - leucopenia, lymphopenia, eosinopenia and elevation of the inflammatory markers. The median values of IL-6, CRP, procalcitonin, d-dimers, and LDH were the highest in the patient with severe disease. Very often, changes in aspartate aminotransferase (AST), bilirubin and albumin could be linked to a number of non-hepatic causes, therefore ALT is used as a more specific marker of acute liver failure (5). According to the used classification of acute liver injury, we observed lack of liver impairment in one of the patients, but the other two (with moderate and severe COVID-19 disease) had a severe form of liver injury with ALT values of 7.7 and 8.3x ULN. The raised baseline values of the liver enzymes in the patient who presented with cholangitis we consider to be the effect of the coexisting biliary sepsis. None of the patients had signs of liver graft dysfunction or graft loss even though immunosuppressive therapy was reduced.

Only one of our patients (the one with severe Covid-19 disease) initially had elevated creatinine levels on admission and developed renal impairment afterwards during the treatment process. Acute kidney injury (AKI) is considered a poor prognostic factor in patients with COVID-19 (4,10). Use of calcineurin inhibitors in a septic state significantly increases the risk of AKI (4). Other poor prognostic factors are comorbidities and more specifically hypertension. In our experience it was namely the patient with the severe Covid-19 infection who suffered from hypertension, diabetes mellitus, obesity, and development of AKI.

The clinical signs of a severe form of COVID-19 are older age, male gender, comorbidities, raised D-Dimer, raised ferritin levels, reduced absolute lymphocyte count, reduced pO2, and the presence of dyspnea on admission $(9,13)$. No significant relation between the time interval from LT and SARS-CoV-2 infection with the disease severity was found. The authors, however, stress the fact that the number of patients diagnosed with COVID-19 in the first year of transplantation are relatively small and further research is needed in order for their findings to be confirmed. The mean time from LT and SARS-CoV-2 infection according to a study from Iran is 60 months (30-156) (6). There were no liver transplantations in Bulgaria since the pandemic was declared on 11.03.2020 up to December 2020. The patient with mild disease was transplanted 1.5 years before because of alcohol abuse 
related cirrhosis while the one with moderate disease - 13 years before due to multiple hemangioendotheliomas. The patient with an LT performed 5 years before as a consequence to $\mathrm{HCV}$ infection had the most severe symptoms.

We had one lethal case as a consequence of respiratory failure. This was the patient with severe disease and comorbidities - diabetes, hypertension, and obesity. In our cohort study of 3 patients the mortality rate was $33.33 \%$. Case-fatality rate of $17 \%-38 \%$ in hospitalized liver transplant recipients is reported in different studies $(6,7,14)$. Colmanero et al. (9) revealed a mortality rate of $18 \%$ in one of the largest epidemiological studies in liver transplant patients with SARS-CoV-2 infection. They came to the conclusion that chronic immunosuppression increases the risk of infection nearly twice and mortality is statistically lower compared to that of the general population. Other authors, however, do not report such difference describing a hospital case-fatality rate of $15-22 \%(15-17)$. The ascertained independent prognostic factors for severe form of COVID-19 (defined in their study as need for ventilatory support, ICU care and/or death) are: Charlson-comorbidity index, male gender, dyspnea at time of diagnosis, and immunosuppressive therapy with mycophenolate mofetil especially in doses over $1000 \mathrm{mg}$ daily. Such correlation is not established with calcineurin inhibitors or everolimus while complete withdrawal of the immunosuppressors did not have any effect. Thus, their recommendation is for reduction or discontinuation of mycophenolate, but the immunosuppressive therapy should not be excluded completely.

A number of authors report the presence of malignancies in high percentage of deceased patients with LT $(7,12)$. Five out of seven patients had a history of cancer of which 3 were in an active form of the disease (7). None of our patients had a history of an active oncological disease. In an international study of 151 liver transplant recipients and COVID19 a multivariable analysis identifies a number of factors associated with higher risk of mortality: older age, elevated serum creatinine levels, the presence of non-liver related malignancy where the time from the transplantation and the type of immunosuppression do not increase that risk (12). The same study did not find the LT to have a negative effect on the COVID-19 prognosis compared with a cohort from UK population without liver transplantation.

Immunosuppression is a key milestone in the COVID-19 outcome. It is still debatable whether immunosuppressive therapy is a risk factor in terms of disease severity, including higher risk of superimposed bacterial infection $(18,19)$ or not. Overdosing immunosuppressants can lead to increased viral load and delayed recovery while, on the other hand, a competent immune system can lead to extremely severe forms of the disease (20). Some authors, based on uncontrolled clinical trials, emphasize the potential positive effect of immunosuppression in COVID-19 (21-23). The negative effect of the mycophenolate is related to its toxic activity on activated lymphocytes (24). SARS-CoV-2 has a direct cytotoxic effect on lymphocytes, especially CD8+ (25) which explains the relation between lymphopenia and poor outcome (26). During previous coronavirus outbreaks such as MERS-CoV and SARS-CoV, Tanaka et al (27) highlighted the ability of calcineurin inhibitors to suppress the coronavirus replication and respectively the cytokine storm (20). In another study the immunosuppressive therapy of liver transplant recipients was left unchanged and the authors concluded that they were responsible for the milder COVID-19 severity (6).

In contrast to the published data our results show mild and moderate disease in the patients with dual immunosuppressive therapy, including mycophenolate mofetil, while our patient with severe disease received only tacrolimus. Most probably, the main factors leading to a severe disease were the patient's comorbidities and the relatively long period of 6 days with symptoms prior to admission when the patient had not received any treatment. All three patients after monitoring the tacrolimus serum levels (all three were 
receiving fluconazole which increases the serum concentration) required dose reduction without having graft dysfunction or rejection. In the cases with dual treatment regimens we did not consider dose reduction or exclusion of mycophenolate which did not have a negative impact on the clinical course, but on the contrary, both had a better outcome eventually.

\section{Conclusion}

Liver transplant recipients are a specific group of patients whose immunosuppressive therapy could have a positive impact on cytokine storm prevention in COVID-19. However, there is an increased risk of superimposed bacterial infection. Early diagnosis and hospitalization are essential for timely initiation of treatment and prevention from complications and development of a severe form of COVID-19 especially in patients with comorbidities such as hypertension, diabetes, and obesity. There may be a dose reduction of the immunosuppressive therapy in the course of treatment, but not exclusion, especially of the calcineurin inhibitor, emphasizing its positive effect in virus replication inhibition and cytokine storm suppression.

\section{Conflicts of Interest}

The authors declare that there is no conflict of interest.

\section{Ethics Approval}

Ethical approval for this study was obtained from the Ethics committee of the Military Medical Academy and informed consent was obtained from all subjects before the study.

\section{References}

1. World Health Organization. Director-General's opening remarks at the media briefing on COVID19-11 March 2020". https://www.who.int/dg/speeches/ detail/who-director-general-s-opening-remarks-at-the-media-briefingoncovid-19-11-march-2020. Accessed April 13, 2020.

2. World Health Organization. Global surveillance for COVID-19 caused by human infection with COVID-19 virus: interim quidance, 20 March 2020. World Health Organization. https://apps.who.int/iris/handle/10665/331506. License: CC BYNC-SA 30 IGO

3. Wong HYF, Lam HYS, Fong AH-T, Leung ST, Chin TWY, Yen Lo CS, et al. Frequency and distribution of chest radiographic findings in positive patients for COVID-19 . Radiology. 2020; 296(2):E72-E78.

4. Lee BT, Perumalswami PV, Im GY, Florman S, Schiano TD, COBE Study Group,
COVID-19 in Liver Transplant Recipients: An Initial Experience From the US Epicenter, Gastroenterology 2020:159(3):1176-1178.

5. Phipps MM, Barraza LH, LaSota ED, Sobieszczyk ME, Pereira MR, Zheng EX, et al. Acute Liver Injury in COVID-19: Prevalence and Association with Clinical Outcomes in a Large U.S. Cohort. Hepatology. 2020;72(3):807-817.

6. Sheikhalipour Z, Kermani TA, Kakaei F, Khalili AF, Vahedi L. Management of COVID-19 in Liver Transplant Recipients with Immunosuppressant Therapy: Experiences of an Iranian Transplant Registry. Exp Clin Transplant. 2021 Jun 3. doi: 10.6002/ect.2020.0526. Online ahead of print.

7. Becchetti C, Zambelli MF, Pasulo Donato LMF, Invernizzi F, Detry 0, Dahlqvist $\mathrm{G}$, et al. COVID-19 in an international European liver transplant recipient cohort. Gut. 2020;69(10):1832-1840.

8. Lovato A, de Filippis C. Clinical Presentation of COVID-19: A Systematic Review Focusing on Upper Airway Symptoms. Ear Nose Throat J. 2020; 99(9):569-576.

9. Colmenero J, Rodríguez-Perálvarez M, Salcedo M, Arias-Milla A, MuñozSerrano A, Graus J, et al. Epidemiological pattern, incidence, and outcomes of COVID-19 in liver transplant patients. J Hepatol. J Hepatol. 2021;74(1): 148155. Epub 2020 Aug 1.

10. Richardson S, Hirsch JS, Narasimhan M, Crawford JM, McGinn T, Davidson KW, et al. Presenting Characteristics, Comorbidities, and Outcomes Among 5700 Patients Hospitalized With COVID-19 in the New York City Area. JAMA. 2020;323(20):2052-2059.

11. Pereira MR, Mohan S, Cohen DJ, Husain SA, Dube GK, Ratner LE, et al. COVID19 in solid organ transplant recipients: Initial report from the US Epicenter. Am J Transplant. 2020; 20(7):1800-1808.

12. Webb GJ, Marjot T, Cook JA, Costica Aloman 4, Armstrong MJ, Brenner EJ, et al. Outcomes following SARS-CoV-2 infection in liver transplant recipients: an international registry study. Lancet Gastroenterol Hepatol. 2020; 5(11):1008-1016

13. Guan WJ, Ni ZY, Hu Y, Liang WH, Ou CQ, He JX, et al. Clinical characteristics of coronavirus disease 2019 in China. N Engl J Med. 2020;382(18): 1708-1720.

14. Nacif $L S$, Zanini $L Y$, Waisberg DR, Pinheiro RS, Galvăo $F$, Andraus W, et al. COVID-19 in solid organ transplantation patients: A systematic review. Clinics (Sao Paulo). 2020;75:e1983.

15. Huang C, Wang Y, Li X, Ren L, Zhao J, Hu Y, et al. Clinical features of patients infected with 2019 novel coronavirus in Wuhan, China. Lancet. 2020; 395(10223):497-506.

16. Wu C, Chen X, Cai Y, Xia J, Zhou X, Xu S, et al. Risk Factors Associated With Acute Respiratory Distress Syndrome and Death in Patients With Coronavirus Disease 2019 Pneumonia in Wuhan, China. JAMA Intern Med. 2020; 180(7):934-943.

17. Richardson S, Hirsch JS, Narasimhan M, Crawford JM, McGinn T, Davidson KW, et al. Presenting Characteristics, Comorbidities, and Outcomes Among 5700 Patients Hospitalized With COVID-19 in the New York City Area. JAMA. 2020;323(20):2052-2059

18. Pereira MR, Mohan S, Cohen DJ, Husain SA, Dube GK, Ratner LE, et al. COVID19 in solid organ transplant recipients: Initial report from the US epicenter. Am J Transplant. 2020; 20(7):1800-1808

19. Fishman JA. Infection in solid-organ transplant recipients. N Engl J Med. 2007;357(25):2601-14.

20. Willicombe M, Thomas D, McAdoo S. COVID-19 and calcineurin inhibitors: should they get left out in the storm? J Am Soc Nephrol. 2020;31(6):1145-1146.

21. Webb GJ, Moon AM, Barnes E, Barritt AS, Marjot T. Determining riskfactors for mortality in liver transplant patients with COVID-19. Lancet Gastroenterol Hepatol 2020;5:P643-P644;

22. Bhoori S, Rossi RE, Citterio D, Mazzaferro V. COVID-19 in long-term liver transplant patients: preliminary experience from an Italian transplant centre in Lombardy. Lancet Gastroenterol Hepatol. 2020;5(6):532-533.

23. D'Antiga L. Coronaviruses and Immunosuppressed Patients: The Facts During the Third Epidemic. Liver Transpl. 2020;26(6):832-834.

24. Allison AC, Eugui EM. Mycophenolate mofetil and its mechanisms of action. Immunopharmacology 2000;47:85-118.

25. Wang $F$, Nie J, Wang $H$, Zhao Q, Xiong $Y$, Deng $L$, et al. Characteristics of peripheral lymphocyte subset alteration in COVID-19 pneumonia. J Infect Dis. 2020:221(11):1762-1769

26. Guan WJ, Ni ZY, Hu Y, Liang WH, Ou CQ, He JX, et al. Clinical characteristics of coronavirus disease 2019 in China. N Engl J Med. 2020;382(18):1708-20.

27. Tanaka $Y$, Sato $Y$, Sasaki T. Suppression of coronavirus replication bycyclophilin inhibitors. Viruses. 2013;5(5):1250-60. 